\title{
Hydrogen Peroxide in the Rainwater of Sao Paulo Megacity: Measurements and Controlling Factors
}

\author{
Carolina Gonçalves, ${ }^{a}$ Marcos A. dos Santos, ${ }^{b}$ Adalgiza Fornaro ${ }^{c}$ and Jairo J. Pedrotti*, ${ }^{*}$ \\ ${ }^{a}$ Departamento de Química, Centro de Ciências e Humanidades, Universidade Presbiteriana \\ Mackenzie, Rua da Consolação, 896, 01302-907 São Paulo-SP, Brazil \\ ${ }^{b}$ Departamento de Química Fundamental, Universidade de São Paulo, Av. Prof. Lineu Prestes, 748, \\ 05508-000 São Paulo-SP, Brazil \\ ${ }^{c}$ Departamento de Ciências Atmosféricas, Universidade de São Paulo, Rua do Matão, 1226, \\ 05508-090, São Paulo-SP, Brazil
}

\begin{abstract}
Determinações de $\mathrm{H}_{2} \mathrm{O}_{2}$, íons majoritários e parâmetros meteorológicos foram realizados em eventos de chuva no centro de São Paulo entre julho de 2001 e janeiro de 2006. As concentrações

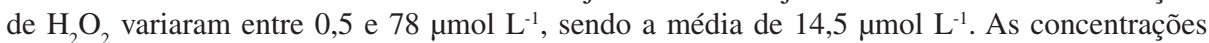
médias de $\mathrm{SO}_{4}{ }^{2-}$ e $\mathrm{HCOO}^{-}$foram 13,5 e 9,62 $\mu \mathrm{mol} \mathrm{L} \mathrm{L}^{-1}$, respectivamente. Observou-se uma correlação significativa de $\mathrm{H}_{2} \mathrm{O}_{2}$ com íon $\mathrm{HCOO}^{-}(r=0,70, n=129, p<0,0001)$ indicando que a oxidação de formaldeído por radicais $\mathrm{OH}^{*}$ pode ser uma rota de formação de $\mathrm{H}_{2} \mathrm{O}_{2}$ nas águas de chuva de São Paulo. A estimativa da deposição úmida de $\mathrm{H}_{2} \mathrm{O}_{2}$ mostra que aproximadamente $70 \%$ da deposição úmida anual de $\mathrm{H}_{2} \mathrm{O}_{2}$ ocorre na primavera e verão. A ocorrência de relâmpagos, assim como a intensidade da chuva, foi importante no controle da concentração de $\mathrm{H}_{2} \mathrm{O}_{2}$ na fase líquida da atmosfera.
\end{abstract}

Measurements of $\mathrm{H}_{2} \mathrm{O}_{2}$, major ions and meteorological parameters were made in rain events occurred in downtown Sao Paulo City, Brazil between July 2001 and January 2006. The $\mathrm{H}_{2} \mathrm{O}_{2}$ concentration ranged from 0.5 to $78 \mu \mathrm{mol} \mathrm{L}{ }^{-1}$ with an average of $14.5 \mu \mathrm{mol} \mathrm{L} \mathrm{L}^{-1}$. The $\mathrm{SO}_{4}^{2-}$ and $\mathrm{HCOO}^{-}$concentrations mean were of 13.5 and $9.62 \mu \mathrm{mol} \mathrm{L}^{-1}$, respectively. The $\mathrm{H}_{2} \mathrm{O}_{2}$ concentrations showed a positive and significant correlation with $\mathrm{HCOO}^{-}(r=0.70, n=129, p<0.0001)$ suggesting that the production of $\mathrm{H}_{2} \mathrm{O}_{2}$ in aqueous phase by consumption of formaldehyde by reaction with $\mathrm{OH}^{*}$ radical is a factor which may control the $\mathrm{H}_{2} \mathrm{O}_{2}$ levels in the rainwater samples. Estimation of rate of wet deposition of $\mathrm{H}_{2} \mathrm{O}_{2}$ shows that nearly $70 \%$ of hydrogen peroxide is annually removed from the atmosphere by wet deposition in spring and summer. Sequential rainstorm analyses indicated that lightning activity and rainfall rate can influence the $\mathrm{H}_{2} \mathrm{O}_{2}$ contents in rainwater in this area.

Keywords: hydrogen peroxide, rainwater, air pollution, megacity

\section{Introduction}

Photochemical oxidants like hydrogen peroxide $\left(\mathrm{H}_{2} \mathrm{O}_{2}\right)$ and ozone $\left(\mathrm{O}_{3}\right)$ are air pollutants which cause adverse effects on plants and crops as well as on the human health. The hydrogen peroxide, $\mathrm{H}_{2} \mathrm{O}_{2}$ is one of the most important oxidants of the troposphere contributing to control the chemical composition of the atmosphere at trace gas levels. ${ }^{1}$ In the gas phase, the $\mathrm{H}_{2} \mathrm{O}_{2}$ production results from the interactions among hydroperoxyl $\left(\mathrm{HO}_{2}{ }^{\circ}\right)$ radicals and hydrated hydroperoxy $\left(\mathrm{H}_{2} \mathrm{O} \cdot \mathrm{HO}_{2}\right)$, which are produced

*e-mail: jpedrotti@mackenzie.br by photolysis of ozone $\left(\mathrm{O}_{3}\right)$ in atmosphere containing sufficiently high humidity and gases such as $\mathrm{CO}$ and hydrocarbons, some of those provided naturally and others resulting from anthropogenic activities. ${ }^{2-4}$

Hydrogen peroxide is extremely soluble in water $\left(\mathrm{K}_{\mathrm{H}}=1.2 \times 10^{5} \mathrm{~mol} \mathrm{~L}^{-1} \mathrm{~atm}^{-1}\right.$ at $\left.25^{\circ} \mathrm{C}\right)$, providing micromolar concentration levels even when the gaseous concentration is within ppbv range..$^{5-7}$ Gas-to-drop partitioning has been considered the predominant source of $\mathrm{H}_{2} \mathrm{O}_{2}$ in atmospheric water drops. On the other hand, some results have shown that solar UV radiation can initiate the photochemical reactions in aqueous phase for $\mathrm{H}_{2} \mathrm{O}_{2}$ formation. ${ }^{8}$ In the liquid phase, the hydrogen peroxide is considered the most 
effective oxidant for the conversion of dissolved sulfur dioxide $\left(\mathrm{SO}_{2}\right)$ to sulfuric acid $\left(\mathrm{H}_{2} \mathrm{SO}_{4}\right)$ at $\mathrm{pH}$ range from 2 to 5 , which is the main contributor to the acidification of cloud, fog and rainwater. ${ }^{5-8}$ The $\mathrm{H}_{2} \mathrm{O}_{2}$ role over continents and oceans has been extensively studied in the atmospheric chemistry, showing that the $\mathrm{H}_{2} \mathrm{O}_{2}$ ambient concentration varies typically from 0.1 to $2.0 \mathrm{ppb}$ in the gas phase and from $<10^{-7}$ to $10^{-4} \mathrm{~mol} \mathrm{~L}^{-1}$ in fog, cloud, snow and rainwater. Higher concentrations have been observed in the summer and lower concentrations in the winter. ${ }^{9-12}$

Field $\mathrm{H}_{2} \mathrm{O}_{2}$ measurements have been carried out by several groups in Southern Hemisphere. ${ }^{13-16}$ In Brazil, the first $\mathrm{H}_{2} \mathrm{O}_{2}$ concentrations in rainwater were measured in the late summer of 1988 in three northeastern sampling sites of the Country (Mucugé, Itaparica Island and Salvador City) in Bahia State. The $\mathrm{H}_{2} \mathrm{O}_{2}$ concentrations showed values ranging from 19 to $200 \mu \mathrm{mol} \mathrm{L}^{-1}$, with an average concentration of $66 \mu \mathrm{mol} \mathrm{L}{ }^{-1} \cdot{ }^{13}$ More recently, two other studies concerning $\mathrm{H}_{2} \mathrm{O}_{2}$ field measurements were carried in urban areas in the Southeastern of the country. In Minas Gerais State, rains collected in Juiz de Fora City between November 2003 and January 2005 showed $\mathrm{H}_{2} \mathrm{O}_{2}$ concentrations ranging from 1.1 to $92.5 \mu \mathrm{mol} \mathrm{L}^{-1}$, being the higher $\mathrm{H}_{2} \mathrm{O}_{2}$ levels measured during spring and summer. ${ }^{15}$ In urban area of Sao Paulo City, lower concentrations were recorded in rainwater collected between April 2003 and April 2004. The concentrations of $\mathrm{H}_{2} \mathrm{O}_{2}$ ranged from 2.29 to $48.6 \mu \mathrm{mol} \mathrm{L}^{-1}$, with an average value of $13.1 \mu \mathrm{mol} \mathrm{L}^{-1}{ }^{16}$

In this work, the results of a 5-year study concerning the measurements of hydrogen peroxide, sulfate, formate, $\mathrm{pH}$ and electrical conductivity in Sao Paulo rainwater are presented and the factors controlling the levels of $\mathrm{H}_{2} \mathrm{O}_{2}$ are discussed. Sequential measurements of $\mathrm{H}_{2} \mathrm{O}_{2}$ in rainstorms were also carried out in order to evaluate the influence of meteorological factors on the $\mathrm{H}_{2} \mathrm{O}_{2}$ concentrations during the precipitation.

\section{Site sampling}

The Metropolitan Area of Sao Paulo (MASP) is located in the southeastern region of Sao Paulo State (46.43' W and $23^{\circ} 34^{\prime} \mathrm{S}$ ), Brazil, around $45 \mathrm{~km}$ from the coast (Atlantic Ocean), at $780 \mathrm{~m}$ above the sea level. The MASP annual climatological data are: average temperature $19.3^{\circ} \mathrm{C}$; relative humidity $78 \%$ and precipitation in $1455 \mathrm{~mm}$. The rainy $(689 \pm 122 \mathrm{~mm})$ periods between December and February and dry ones $(135 \pm 67 \mathrm{~mm}$ ) between June and August are well-defined, summer and winter, respectively. Intermediary situations happen in the fall and in the spring. ${ }^{17}$ Sao Paulo City has, approximately, 11 million inhabitants and it is the largest part of the MASP, one of the most populated urban regions in the world, with more than 19 million inhabitants distributed in $1,747 \mathrm{~km}^{2}$ of unplanned urban area, characterized by serious environmental problems. ${ }^{18}$

Sao Paulo State Environmental Agency (CETESB) has been monitoring atmospheric pollutants like $\mathrm{SO}_{2}, \mathrm{CO}, \mathrm{NO}_{x}$, $\mathrm{O}_{3}$ and inhalable particulates $\left(\mathrm{PM}_{10}\right)$ by an automatic network in the MASP (29 sites). In the last years, these results have indicated that the atmospheric emissions in the MASP are associated with pollutants released, mainly, by the large fleet of vehicles. The most common fuels used by almost seven million heavy and light vehicles are diesel, hydrated ethanol and gasohol (gasoline $+22 \%$ of ethanol). The vehicular fleet has been responsible for $97 \%$ of $\mathrm{CO}, 97 \%$ of $\mathrm{HC}, 96 \%$ of $\mathrm{NO}_{\mathrm{x}}, 35 \%$ of $\mathrm{SO}_{2}$ and $40 \%$ of $\mathrm{PM}_{10}$ emissions. ${ }^{18}$

Although there is no monitoring net about rainwater chemical composition in Sao Paulo, recent results show that ammonium $\left(\mathrm{NH}_{4}^{+}\right)$is the dominant ion, followed by nitrate $\left(\mathrm{NO}_{3}^{-}\right)$, sodium $\left(\mathrm{Na}^{+}\right)$, sulfate $\left(\mathrm{SO}_{4}{ }^{2-}\right)$ and formate $\left(\mathrm{HCOO}^{-}\right)$. The average $\mathrm{pH}$ value was 5.1 , indicating that the precipitation was slightly acidic..$^{19,20}$

\section{Experimental}

Rainwater samples were collected in high-density polyethylene bottles at the Mackenzie University campus located in downtown Sao Paulo City. The automatic wet-only sample collector (G.K. Walter Germany) is positioned at the balcony of the Education Building, $15 \mathrm{~m}$ above the ground. Preliminary experiments carried out with rainwater samples showed that $\mathrm{H}_{2} \mathrm{O}_{2}$ concentration suffer a decrease $30-50 \%$ within a period of $2 \mathrm{~h}$ after their collection at ambient temperature. The conditioning of the samples carried out at $-18^{\circ} \mathrm{C}$ or at $-80{ }^{\circ} \mathrm{C}$ in order to preserve the $\mathrm{H}_{2} \mathrm{O}_{2}$ content did not show good results. A significant $\mathrm{H}_{2} \mathrm{O}_{2}$ decomposition was observed in both temperatures, although the fastest process occurred at $-18^{\circ} \mathrm{C}$. So, the $\mathrm{H}_{2} \mathrm{O}_{2}$ determination was made only in samples collected during or immediately after the end of the rain events. Usually within $15 \mathrm{~min}$ after their collection, the rainwater samples were filtered through a $0.22 \mu \mathrm{m}$ pore size cellulose acetate membrane and analyzed for $\mathrm{H}_{2} \mathrm{O}_{2}$. The remaining sample volume were separated into aliquots and stored in a freezer $\left(\right.$ at $\left.-18{ }^{\circ} \mathrm{C}\right)$ for additional analytical determinations, which were made within 2 weeks after their collection. Meteorological data were obtained from the Meteorological Station (IAG/USP).

\section{Reagents and chemicals}

All chemicals were reagents of analytical grade and were used without further purification. Hydrogen peroxide, 
4-aminoantipyrine, mono and di-hydrogen phosphate were obtained from Merck (Darmstadt, Germany). Peroxyacetic acid was purchased from Aldrich (Milwaukee, WI, USA). Phenol, commercial catalase and peroxidase were obtained from Sigma (St. Louis, MO, USA). Solutions were prepared with deionized water (Nanopure system, resistivity $>18 \mathrm{M} \Omega \mathrm{cm}$ ). The stock solution containing $0.10 \mathrm{~mol} \mathrm{~L}^{-1}$ $\mathrm{H}_{2} \mathrm{O}_{2}$ was stored at $4{ }^{\circ} \mathrm{C}$ and standardized with $\mathrm{KMnO}_{4}$, which had previously been standardized with sodium oxalate. The reference solutions of $\mathrm{H}_{2} \mathrm{O}_{2}$ were prepared just before their use by dilution of the stock solution.

\section{Instrumentation}

Flow spectrophotometric measurements were made by using a model 600 Femto visible spectrophotometer (Sao Paulo, Brazil) provided with a $180 \mu \mathrm{L}$ glass flow cell with a $1.0 \mathrm{~cm}$ light path. The solutions were propelled with an Ismatec pump model REGLO. Teflon tubing of $0.8 \mathrm{~mm}$ i.d. was used for manifold construction except for pump tubing, where short sections of Tygon tubing were employed. Sample and colorimetric reagent solutions were injected in the FIA system with a homemade, manually operated, rotatory valve provided with $500 \mu \mathrm{L}$ sampling loops.

The $\mathrm{pH}$ values were measured using a Digimed DM-20 $\mathrm{pH}$-meter provided with a glass electrode combined with an $\mathrm{Ag} / \mathrm{AgCl}$ ( $\mathrm{KCl}$ sat.) reference electrode. The anions analyses were made by ion chromatography Metrohm model 761 with an electrical conductivity detector. The mobile phase was a $4.0 \mathrm{mmol} \mathrm{L}^{-1} \mathrm{Na}_{2} \mathrm{CO}_{3} / 1.2 \mathrm{mmol} \mathrm{L}^{-1} \mathrm{NaHCO}_{3}$ solution and the suppressor column was regenerated with $50 \mathrm{mmol} \mathrm{L}^{-1} \mathrm{H}_{2} \mathrm{SO}_{4}$. Acetaldehyde and formaldehyde were measured as 2,4 dinitrophenylhydrazones (DNPH) derivatives by using a Dionex P680 liquid chromatograph with a $20 \mu \mathrm{L}$ sampling loop and $340 \mathrm{U}$ UV detector operating at $360 \mathrm{~nm}$. The separation of the hydrazones was carried out with $\mathrm{C}_{18}$ reversed phase Supersil ODS column $(5 \mu \mathrm{m}, 4.6 \times 150 \mathrm{~mm})$ with isocratic elution by using a $30 / 70 \%(\mathrm{v} / \mathrm{v})$ water-acetonitrile solution at $0.7 \mathrm{~mL} \mathrm{~min}^{-1}$ flow rate as mobile phase. ${ }^{21}$

\section{Hydrogen peroxide analysis}

A flow injection method with spectrophotometric detection was used for hydrogen peroxide determination. ${ }^{22}$ The analytical method is based on the one-electron oxidation of phenol by hydrogen peroxide catalyzed by peroxidase. The phenoxy radicals react with 4-aminoantipyrine and hydrogen peroxide to generate an antipyrilquinoimine red product, which exhibits the maximum absorption at $505 \mathrm{~nm}$. The absorbance signal is proportional to the rate of $\mathrm{H}_{2} \mathrm{O}_{2}$ consumption, which is also dependent on the concentration of active enzyme in the solution. A schematic diagram of the FI analytical method is shown in Figure 1.

The analytical method obeys the Beer's law in a concentration range of $0.5-100 \mu \mathrm{mol} \mathrm{L}^{-1}$ of hydrogen peroxide with an excellent correlation coefficient $(r=0.9998)$ and a limit of detection of $0.3 \mu \mathrm{mol} \mathrm{L}^{-1}$ $\left(10.2 \mu \mathrm{g} \mathrm{L}^{-1}\right)$ at $\mathrm{pH}$ 7.0. At a flow rate of $1.2 \mathrm{~mL} \mathrm{~min}^{-1}$, a sampling rate of 50 injections per hour can be reached and the relative standard deviation, RSD of the peak signals are better than $2 \%$. The accuracy of the analytical method was evaluated from recovery tests made by fortification of rainwater samples with hydrogen peroxide concentration in 4 up to $20 \mu \mathrm{mol} \mathrm{L}^{-1}$ range. The recovery results carried out with five different rainwater samples showed values ranging from 97 to $101 \%(\mathrm{n}=3)$. Organic hydroperoxides such as methyl hydroperoxide $\left[\mathrm{CH}_{3} \mathrm{O}_{2} \mathrm{H}\right]$ and peroxyacetic acid $\left[\mathrm{CH}_{3} \mathrm{C}(\mathrm{O}) \mathrm{O}_{2} \mathrm{H}\right]$, which are often present in rainwater samples, do not interfere in the determination of hydrogen peroxide. All measurements were made at room temperature $\left(25 \pm 1{ }^{\circ} \mathrm{C}\right)$.

\section{Results and Discussion}

Between July 2001 and January 2006 the rainwater was collected in the central area of Sao Paulo City and analyzed for $\mathrm{H}_{2} \mathrm{O}_{2}, \mathrm{SO}_{4}^{2-}, \mathrm{HCOO}^{-}, \mathrm{pH}$ and electrical conductivity. The rainfall sampled was $1,067 \mathrm{~mm}$, corresponding to $25 \%$ of the total precipitation in the period in this area. Most rainfall occurred between September and February months

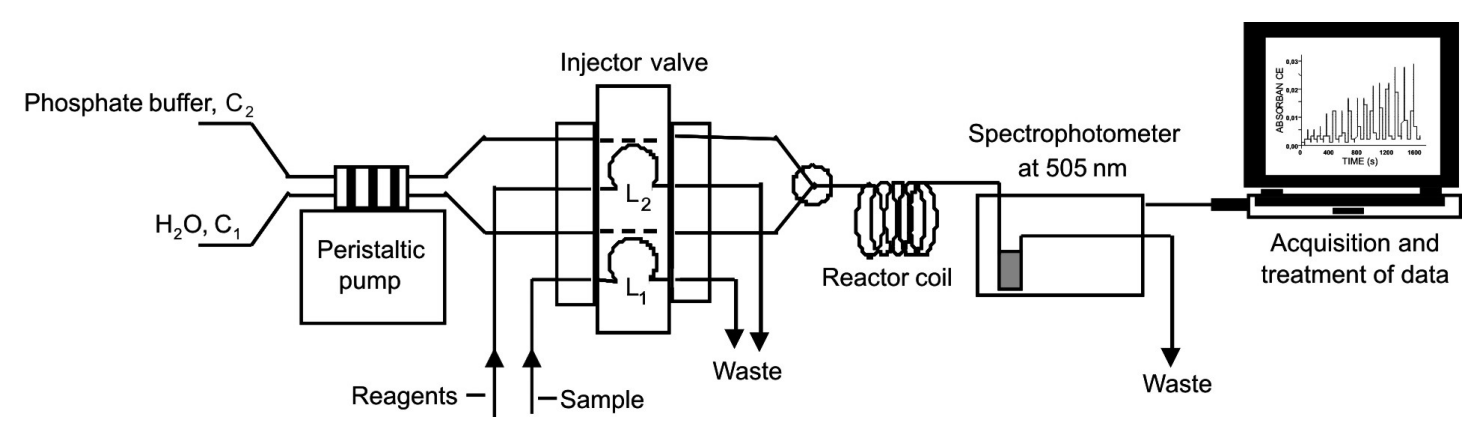

Figure 1. FIA system scheme with merging zone for $\mathrm{H}_{2} \mathrm{O}_{2}$ determination. 
Table 1. Statistical information about hydrogen peroxide, sulfate and formate concentrations, $\mathrm{pH}$ and conductivity values in rainwater samples collected in downtown Sao Paulo City, June 2001-January 2006

\begin{tabular}{lcccccc}
\hline Species & $\mathrm{n}$ & Min. & Max. & Median & Mean $( \pm \mathrm{sd})$ & VWM \\
\cline { 3 - 6 } & & & & $\mu \mathrm{mol} \mathrm{L} \mathrm{L}^{-1}$ & & \\
\hline$\left[\mathrm{H}_{2} \mathrm{O}_{2}\right]$ & 180 & $<$ LOD & 78.1 & 10.4 & $14.5(13.4)$ & 12.4 \\
{$\left[\mathrm{SO}_{4}{ }^{2-}\right]$} & 129 & 0.60 & 62.5 & 9.26 & $13.5(12.4)$ & 11.7 \\
{$\left[\mathrm{HCOO}^{-}\right]$} & 129 & 0.12 & 72.3 & 3.94 & $9.62(14.4)$ & 7.86 \\
$\mathrm{pH}$ & 175 & 4.13 & 7.18 & 5.50 & 5.10 & 5.14 \\
Conductivity $\left(\mu \mathrm{S} \mathrm{cm}^{-1}\right)$ & 175 & 2.01 & 52.7 & 11.8 & 15.7 & \\
\hline
\end{tabular}

$\mathrm{n}=$ sample number, $\mathrm{LOD}=$ limit of detection $(0.3 \mu \mathrm{mol} \mathrm{L}-1)$.

(spring and summer seasons), corresponding to $786 \mathrm{~mm}$ precipitation amount.

Table 1 shows the statistical data of the hydrogen peroxide, sulfate and formate concentrations, $\mathrm{pH}$ and conductivity values for rainwater samples. The $\mathrm{H}_{2} \mathrm{O}_{2}$

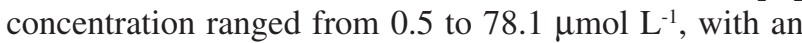
average value of $14.5 \mu \mathrm{mol} \mathrm{\textrm {L } ^ { - 1 }}$. The hydrogen peroxide concentrations measured in Sao Paulo megacity showed higher variation than those measured in rainwater sampled in Salvador, Bahia (Brazil) and Miami, Florida (EUA). ${ }^{13,23}$ The higher seasonal variation in sunlight and the more polluted air in Sao Paulo, when compared with the two other cities, may explain the difference in variation of $\mathrm{H}_{2} \mathrm{O}_{2}$ concentrations.

The higher concentrations $\left(>50 \mu \mathrm{mol} \mathrm{L}^{-1}\right.$ ) of $\mathrm{H}_{2} \mathrm{O}_{2}$ were observed in four rain events in 9/20/2002, 9/13/2003, $1 / 15 / 04$ and 10/26/2005. All these rain showers occurred at early afternoon (between 1:00 and 3:00 pm) and were preceded by mornings with intense solar radiation and high temperature, which favors the photochemical process into the atmosphere and accelerates the formation of $\mathrm{HO}_{2}$ radicals and the production of $\mathrm{H}_{2} \mathrm{O}_{2}$.

The volume-weighted mean $\mathrm{H}_{2} \mathrm{O}_{2}$ concentration was $12.4 \mu \mathrm{mol} \mathrm{L} \mathrm{L}^{-1}$. This value was much lower than those concentrations measured in Brazilian urban areas of Salvador, ${ }^{13}$ Bahia, $124 \mu \mathrm{mol} \mathrm{L^{-1 }}$ and Juiz de Fora, ${ }^{15}$ Minas Gerais, $23.4 \mu \mathrm{mol} \mathrm{L}{ }^{-1}$ but almost two times higher than that in Santiago, ${ }^{10}$ Chile, $6.6 \mu \mathrm{mol} \mathrm{L} \mathrm{L}^{-1}$ and Miami, ${ }^{23}$ Florida, $6.9 \mu \mathrm{mol} \mathrm{\textrm {L } ^ { - 1 }}$ and similar to that in Mexico City, ${ }^{12}$ $11.2 \mu \mathrm{mol} \mathrm{L}{ }^{-1}$

The concentrations of $\mathrm{H}_{2} \mathrm{O}_{2}$ exhibited a significant seasonal variability (Figure $2 \mathrm{a}$ ). The higher $\mathrm{H}_{2} \mathrm{O}_{2}$ concentrations were measured in the spring rains (September-November) (average $=20.7 \mu \mathrm{mol} \mathrm{L} \mathrm{L}^{-1}$, $\mathrm{n}=61$ ) while the lower concentrations were obtained in rainwater samples collected in winter (June-August) (mean $=8.6 \mu \mathrm{mol} \mathrm{L} \mathrm{L}^{-1}, \mathrm{n}=10$ ). The spring season is characterized by strong solar radiation and higher biogenic emission of volatile organic compounds (VOCs) to the atmosphere, which favors the $\mathrm{H}_{2} \mathrm{O}_{2}$ production in the gas phase and the aqueous phase. Results obtained from air quality monitoring in MASP indicate that maximum ozone concentrations have also been observed in spring (Figure 2b), emphasizing the increase of the photochemical processes into the atmosphere in this season. ${ }^{18}$
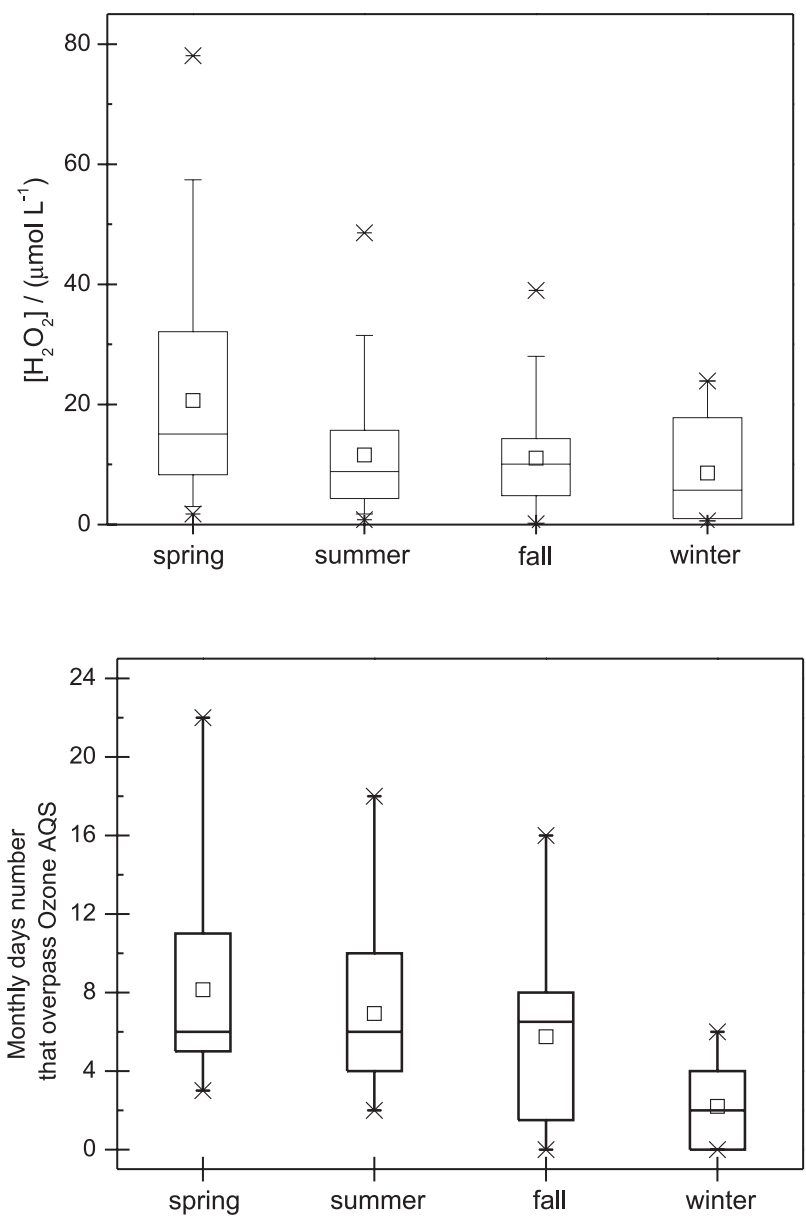

Figure 2. Box and whisker plots of (A) $\mathrm{H}_{2} \mathrm{O}_{2}$ concentrations in different seasons in Sao Paulo City rainwater and (B) monthly number of days that overpass the ozone Air Quality Standard (AQS $=160 \mu \mathrm{g} \mathrm{m}^{-3}$, CETESB), for period between July 2001 and January 2006. Horizontal lines in the box: $25^{\text {th }}, 50^{\text {th }}$ and $75^{\text {th }}$ percentile values; error bars: $5^{\text {th }}$ and $95^{\text {th }}$ percentile values; $\square$ arithmetic mean; (*) minimum and maximum values. 
The $\mathrm{pH}$ values ranged from 4.13 to 7.18 , presenting a mean value of 5.10 and VWM of 5.14 (Table 1). More than $55 \%$ of the rainwater had a $\mathrm{pH}$ value between 5.0 and 5.5 and almost $23 \%$ of the samples presented $\mathrm{pH}$ values lower than 5.0. The average $\mathrm{pH}$ determined in this six-year study was higher than that measured in two other wet-only studies conducted in the West side of Sao Paulo City during the late 1980s and mid-1990s, which obtained mean $\mathrm{pH}$ values of $4.5(n=450)$ and $4.5(n=27)$, respectively. ${ }^{17}$

Classically, the results registered in literature indicate that $\mathrm{H}_{2} \mathrm{O}_{2}$ is the main oxidant for $\mathrm{SO}_{2}$ in the atmospheric liquid phase at $\mathrm{pH}$ values $<5$, which can result in negative correlation between $\mathrm{H}_{2} \mathrm{O}_{2}$ and $\mathrm{SO}_{4}^{2-}$ concentrations in rainwater. ${ }^{24}$ Nevertheless, a low positive and significant correlation $(r=0.37, \mathrm{n}=129, p<0.0001)$ between $\mathrm{H}_{2} \mathrm{O}_{2}$ and $\mathrm{SO}_{4}{ }^{2-}$ was obtained in this study, as it can be seen in Figure 3A. Additionally, Figure 3B shows that higher $\mathrm{H}_{2} \mathrm{O}_{2}$ concentrations were observed in samples with $\mathrm{pH}$ values $<5$, indicating that the destruction of hydrogen peroxide by sulfur dioxide is not the predominant factor controlling $\mathrm{H}_{2} \mathrm{O}_{2}$ in the rainwater of this area. The positive correlation could be a result of higher concentration of $\mathrm{H}_{2} \mathrm{O}_{2}$ precursors in liquid phase with other pollutants that generate $\mathrm{SO}_{4}{ }^{2-}$ in rain, such as the dissolution of particulate matter as well as the oxidation of $\mathrm{SO}_{2}$ in gaseous phase with transfer to the liquid phase. .9,24 $^{1,4}$

A significant correlation $(r=0.70, p<0.0001)$ was observed between $\mathrm{H}_{2} \mathrm{O}_{2}$ and $\mathrm{HCOO}^{-}$concentration (Figure $3 \mathrm{C}$ ) suggesting the production of $\mathrm{HCOO}^{-}$and $\mathrm{H}_{2} \mathrm{O}_{2}$ by reactions in aqueous phase through formaldehyde oxidation by $\mathrm{OH}^{*}$ radical. ${ }^{25}$ The reactions begin with the $\mathrm{HCHO}$ dissolution in the atmospheric aqueous phase (intrinsic Henry's constant, $\mathrm{H}=1.3 \mathrm{~mol} \mathrm{~L}^{-1} \mathrm{~atm}^{-1}$ ), followed by its hydration which increases its solubility (effective Henry's constant $\mathrm{H}^{*}=3.0 \times 10^{3} \mathrm{~mol} \mathrm{~L}^{-1} \mathrm{~atm}^{-1}$ ) and favors the gemdiol (geminal diol) production, reaction $1 .{ }^{25}$ In parallel, there is the radicals dissolution, $\mathrm{OH}^{\cdot}$ and $\mathrm{HO}_{2}{ }^{-}$, Henry's constant, $\mathrm{H}=30$ and $1-3 \times 10^{3} \mathrm{~mol} \mathrm{~L}^{-1} \mathrm{~atm}^{-1}$, respectively, ${ }^{26}$ which favors the oxidation processes (reactions 2-3), producing more radicals and formic acid. The reactions sequences finish with the $\mathrm{H}_{2} \mathrm{O}_{2}$ yielding (reaction 4):

$$
\begin{aligned}
& \mathrm{HCHO}_{(\mathrm{g})}+\mathrm{H}_{2} \mathrm{O} \rightleftharpoons \mathrm{CH}_{2}(\mathrm{OH})_{2} \\
& \mathrm{CH}_{2}(\mathrm{OH})_{2}+\mathrm{OH}^{\cdot} \rightarrow \mathrm{CH}(\mathrm{OH})_{2}^{\cdot}+\mathrm{H}_{2} \mathrm{O} \\
& \mathrm{CH}(\mathrm{OH})_{2}^{\cdot}+\mathrm{O}_{2} \rightarrow \mathrm{HCOOH}+\mathrm{HO}_{2}^{\cdot} \\
& \mathrm{HO}_{2}^{\cdot}+\mathrm{HO}_{2}^{\cdot} \rightarrow \mathrm{H}_{2} \mathrm{O}_{2}+\mathrm{O}_{2}
\end{aligned}
$$

In attempt to interpret these reactions in Sao Paulo rainwater, formaldehyde ( $\mathrm{HCHO}$ ) and acetaldehyde
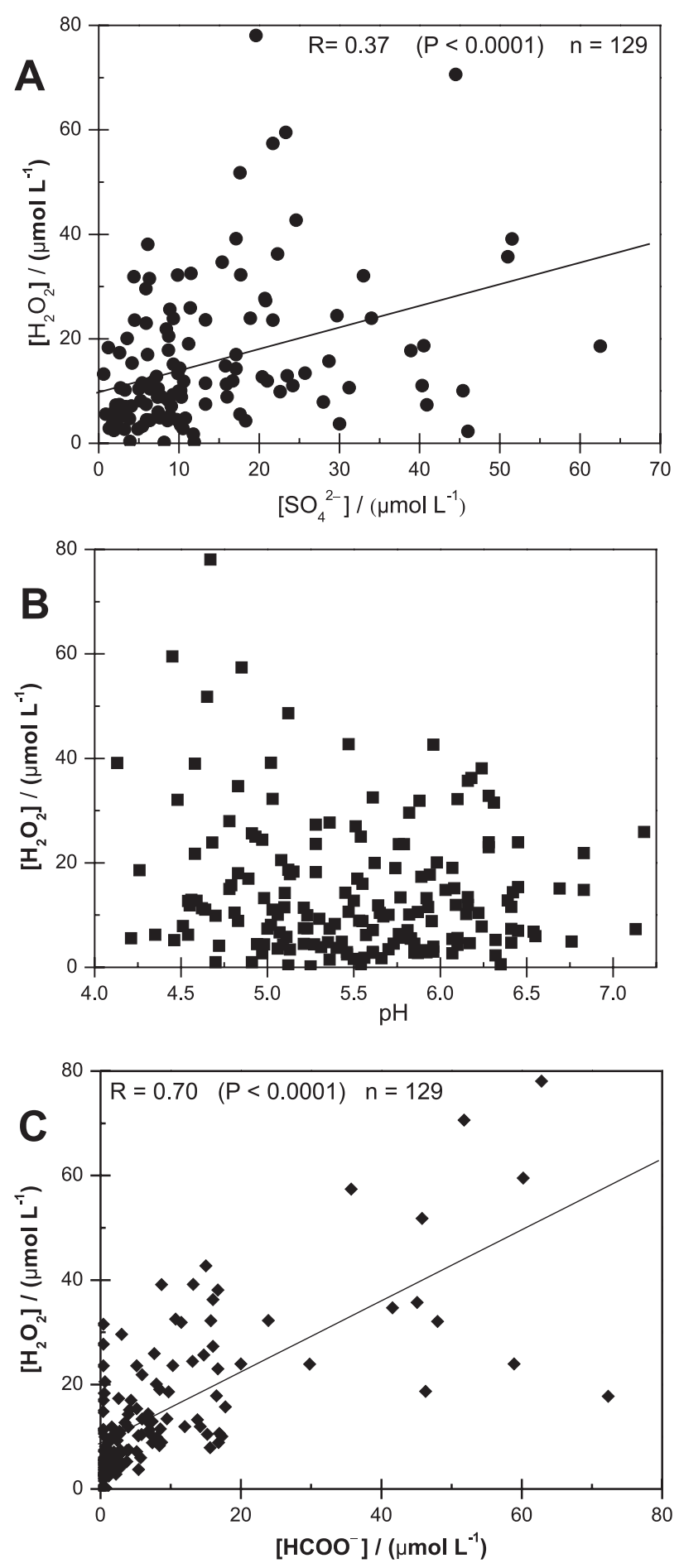

Figure 3. $\mathrm{H}_{2} \mathrm{O}_{2}$ concentration variation vs: (A) $\left[\mathrm{SO}_{4}{ }^{2-}\right]$, (B) $\mathrm{pH}$ and (C) $\left[\mathrm{HCOO}^{-}\right]$.

$\left(\mathrm{H}_{3} \mathrm{CCHO}\right)$ were also measured. Results of this experiment (Table 2) indicate the predominance of acetaldehyde. On the other hand, likewise data shown in Figure 3C, a positive correlation was observed between $\mathrm{H}_{2} \mathrm{O}_{2}$ and $\mathrm{HCOO}^{-}$for this set, even considering the small number of samples. Concentrations of aldehydes 
reported in gas phase of Sao Paulo City are at tens of ppbv levels and shows $\mathrm{HCHO} / \mathrm{H}_{3} \mathrm{CCHO}$ ratio close to one..$^{27,28}$ If these aldehydes concentrations in gas phase are similar, higher [HCHO] should be expected in aqueous phase, talking in account that the $\mathrm{HCHO}$ effective Henry's constant, $\mathrm{H}^{*}=3.0 \times 10^{3} \mathrm{~mol} \mathrm{~L}^{-1}$ atm $^{-1}$ is higher than the $\mathrm{H}_{3} \mathrm{CCHO}, \mathrm{H}^{*}=1.14 \times 10 \mathrm{~mol} \mathrm{~L}^{-1} \mathrm{~atm}^{-1} .26$ However, the results on Table 2 show $\mathrm{H}_{3} \mathrm{CCHO}$ concentrations higher than those of $\mathrm{HCHO}$, suggesting the consumption of gemdiol by reactions with radicals (reactions 2 and 3 ) and the production of $\mathrm{H}_{2} \mathrm{O}_{2}$ and $\mathrm{HCOO}^{-}$.

Table 2. Acetaldehyde, formaldehyde, formate and hydrogen peroxide concentration in rainwater samples in downtown Sao Paulo, corresponding to January $19-31 / 2006$

\begin{tabular}{lcccc}
\hline & $\mathrm{n}$ & Min. & Max. & Mean $( \pm \mathrm{sd})$ \\
\cline { 3 - 5 } & & \multicolumn{3}{c}{$\left.(\mu \mathrm{mol} \mathrm{L})^{-1}\right)$} \\
\hline $\mathrm{CH}_{3} \mathrm{CHO}$ & 12 & 1.32 & 12.8 & $5.69(3.82)$ \\
$\mathrm{HCHO}$ & 12 & 0.10 & 0.20 & $0.11(0.03)$ \\
$\mathrm{HCOO}^{-}$ & 11 & 1.71 & 18.2 & $9.55(6.47)$ \\
$\mathrm{H}_{2} \mathrm{O}_{2}$ & 8 & 3.4 & 31.9 & $16.3(9.4)$ \\
\hline
\end{tabular}

The air temperature ranged from 9 to up $31.3^{\circ} \mathrm{C}$, with and mean value of $22.5^{\circ} \mathrm{C}$. The higher temperature values were measured in the summer and lower in the winter. The relationship between $\mathrm{H}_{2} \mathrm{O}_{2}$ concentration in rainwater and air temperature showed a temperature range between 18 and $26{ }^{\circ} \mathrm{C}$ in which $\mathrm{H}_{2} \mathrm{O}_{2}$ maximum concentrations were observed. This result suggest that reactions of $\mathrm{H}_{2} \mathrm{O}_{2}$ decomposition are predominant in higher temperatures while lower temperatures do not provide favorable conditions for photochemical reactions to production of $\mathrm{H}_{2} \mathrm{O}_{2}$, as previously suggested. ${ }^{16}$

The relationship between the precipitation volume and the concentrations of $\mathrm{H}_{2} \mathrm{O}_{2}$ was investigated using a regression analysis in order to evaluate the influence of rainfall on $\mathrm{H}_{2} \mathrm{O}_{2}$ content in rainwater. Most rainwater samples showed volume $<10 \mathrm{~mm}$. The evaluation of $\mathrm{H}_{2} \mathrm{O}_{2}$ concentrations data versus the rainfall shows a weak correlation ( $r=-0.15, \mathrm{n}=180, p<0.07)$, indicating that the $\mathrm{H}_{2} \mathrm{O}_{2}$ concentrations were not controlled by dilution during these measurements. On the other hand, the regression analysis of $\mathrm{H}_{2} \mathrm{O}_{2}$ concentrations as a function of the precipitation rate showed a significant linear correlation, denoting that lower rainfall rate lead to higher $\mathrm{H}_{2} \mathrm{O}_{2}$ content in several rainstorms, which agrees with the results obtained in $\mathrm{H}_{2} \mathrm{O}_{2}$ rainwater measurements carried out in Salvador area, Bahia. ${ }^{13}$

By using the volume-weighted mean $\mathrm{H}_{2} \mathrm{O}_{2}$ concentration of $12.4 \mu \mathrm{mol} \mathrm{L} \mathrm{L}^{-1}$ and the annual average precipitation amount of $1.0 \mathrm{~m} \mathrm{y}^{-1}$ in this site sampling, the annual rate of $\mathrm{H}_{2} \mathrm{O}_{2}$ wet deposition for this 5-year study was $12 \mathrm{mmol} \mathrm{m}^{-2} \mathrm{y}^{-1}$. Considering the lack of other data for $\mathrm{H}_{2} \mathrm{O}_{2}$ wet deposition in Brazil, the annual wet deposition of $\mathrm{H}_{2} \mathrm{O}_{2}$ was compared with studies conducted in U.S.A. and in Japan. In Sao Paulo, it was slightly higher than that obtained in Kyoto in 1999 and in 2000, 11.7 and $9.11 \mathrm{mmol} \mathrm{m}^{-2} \mathrm{y}^{-1}$, respectively, ${ }^{29}$ and exactly equal to the wet deposition value obtained in Wilmington, North Carolina between 1992 and $1994 .{ }^{30}$ However, it was much higher than the value of $1.5 \mathrm{mmol} \mathrm{m} \mathrm{m}^{-2} \mathrm{y}^{-1}$ found in Los Angeles during 1985-1991. ${ }^{31}$ The lower anual average rain amount $\left(0.34 \mathrm{~m} \mathrm{y}^{-1}\right)$ and the greater decomposition of $\mathrm{H}_{2} \mathrm{O}_{2}$ by reactions with other pollutants in the Los Angeles area may explain this significant difference.

The $\mathrm{H}_{2} \mathrm{O}_{2}$ wet deposition showed significant seasonal variation. Considering that both concentrations and precipitation volume are higher in the spring and summer, nearly $70 \%$ of annual $\mathrm{H}_{2} \mathrm{O}_{2}$ wet deposition occurs between October and February in Sao Paulo City.

\section{Profile of variations of $\mathrm{H}_{2} \mathrm{O}_{2}$ concentrations during some rain events}

In order to investigate the variability patterns of $\mathrm{H}_{2} \mathrm{O}_{2}$ concentrations during the rainstorms in Sao Paulo and the meteorological factors that can influence its concentration, several continuous measurements of $\mathrm{H}_{2} \mathrm{O}_{2}$ were conducted. Most of these measurements were carried out in summer and spring (rainy period) and just one sequential rain sample was collected in fall, which corresponds to dry season. Usually, the rain events in Sao Paulo occur in the afternoon and are preceded by periods of intense solar radiation in spring and summer. Short lasting light showers are frequently observed in fall and winter. The hydrogen peroxide concentration was measured in thirteen rain events and showed three patterns of temporal variation. During the first $10 \mathrm{~mm}$ of rain, the $\mathrm{H}_{2} \mathrm{O}_{2}$ content increased in six events while its concentration declined in five others. An irregular variation in $\mathrm{H}_{2} \mathrm{O}_{2}$ concentration was observed in remaining storms.

Figure 4 shows some examples of temporal variation of $\mathrm{H}_{2} \mathrm{O}_{2}$ concentrations. The rainstorm of October 09, 2003 (Figure 4a) occurred at the middle of the afternoon and was preceded by a sunny morning. The temperature ranged between $22.8{ }^{\circ} \mathrm{C}$ at early morning to $30.1{ }^{\circ} \mathrm{C}$ at midday. From 1:00 pm, the air temperature was slowly decreasing and attained $28.3^{\circ} \mathrm{C}$ at $3: 40 \mathrm{pm}$, when a heavy rain with thunder started. The $\mathrm{H}_{2} \mathrm{O}_{2}$ concentration measured in the initial rain sample (collected at 4:00 pm) was high (21.9 $\mu \mathrm{mol} \mathrm{L}-1)$. The $\mathrm{H}_{2} \mathrm{O}_{2}$ content increased continuously 
during the rainfall, reaching $42.6 \mu \mathrm{mol} \mathrm{L}^{-1}$ in the last sample collected at $6: 25 \mathrm{pm}$. The high $\mathrm{H}_{2} \mathrm{O}_{2}$ concentration in the first sample can be attributed to the photochemical reactions in the atmosphere before the precipitation. The increase of $\mathrm{H}_{2} \mathrm{O}_{2}$ concentration in the following samples could be due to the lightning during thunderstorms in the area producing $\mathrm{H}_{2} \mathrm{O}_{2}$ in clouds. Evidence of the hydrogen peroxide production in rainwater by lightning during thunderstorms was previously suggested. ${ }^{32,33}$ Additionally, the decrease of rainfall rate from the second sample may also have contributed to the increase of $\mathrm{H}_{2} \mathrm{O}_{2}$ concentration in the rainwater.

On November 28, 2002 (Figure 4b), the $\mathrm{H}_{2} \mathrm{O}_{2}$ concentrations were measured in a rainstorm sampled between 2:00 and 5:45 pm. Likewise in October 2003, the precipitation occurred after an intense solar radiation in the morning and in the early afternoon. At 1:00 pm the temperature value attained $32.4{ }^{\circ} \mathrm{C}$, which indicated favorable conditions for photochemical $\mathrm{H}_{2} \mathrm{O}_{2}$ production in the atmosphere. The concentration of $\mathrm{H}_{2} \mathrm{O}_{2}$ in the first sample collected was high, $27.3 \mu \mathrm{mol} \mathrm{L} \mathrm{L}^{-1}$ and it was virtually constant $\left(27.6 \mu \mathrm{mol} \mathrm{L} \mathrm{L}^{-1}\right)$ in the second sample collected between 3:25 and 5:00 pm. Afterwards, the
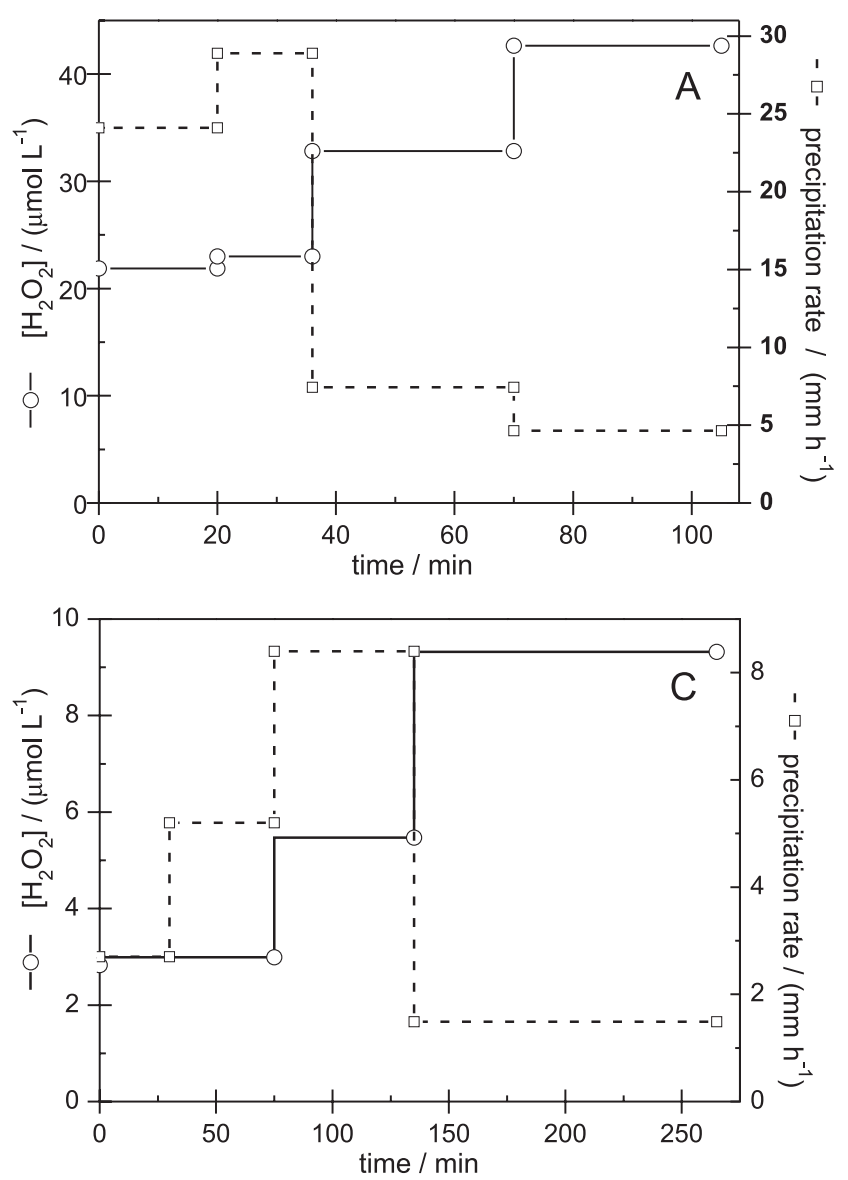

content of $\mathrm{H}_{2} \mathrm{O}_{2}$ started decreasing until the end of the rainstorm, probably due to significant increase in rainfall rate which minimizes the scavenging process of $\mathrm{H}_{2} \mathrm{O}_{2}$ in the atmosphere below clouds.

Figure 4c shows the $\mathrm{H}_{2} \mathrm{O}_{2}$ concentrations for a light shower collected on November 16, 2004 after a rainy night. The diurnal temperature ranged from 19.7 to $21^{\circ} \mathrm{C}$. The precipitation started again in the morning of November 16 and it was preceded by cloudy weather conditions. The $\mathrm{H}_{2} \mathrm{O}_{2}$ concentration was low in the first sample collected at 11:15 am, $2.8 \mu \mathrm{mol} \mathrm{L} \mathrm{L}^{-1}$ and increased up to $9.3 \mu \mathrm{mol} \mathrm{L}^{-1}$, measured in the forth sample collected when the rain was over at 3:40 pm. This is an indicative that even in rainy days the photochemical production of hydrogen peroxide in the atmosphere is enough to increase the $\mathrm{H}_{2} \mathrm{O}_{2}$ levels in rainwater. A similar pattern of variation in $\mathrm{H}_{2} \mathrm{O}_{2}$ concentrations was found in precipitation collected in warm season of North Carolina. ${ }^{30}$

The rainstorm of September 20, 2002 (Figure 4d) started at 1:30 pm after a partial cloudy morning. At the beginning, $\mathrm{H}_{2} \mathrm{O}_{2}$ concentration was $18.7 \mu \mathrm{mol} \mathrm{L}-1$, rising to 51.8 and to $78.1 \mu \mathrm{mol} \mathrm{L}^{-1}$ up to the first $5 \mathrm{~mm}$ of rain.
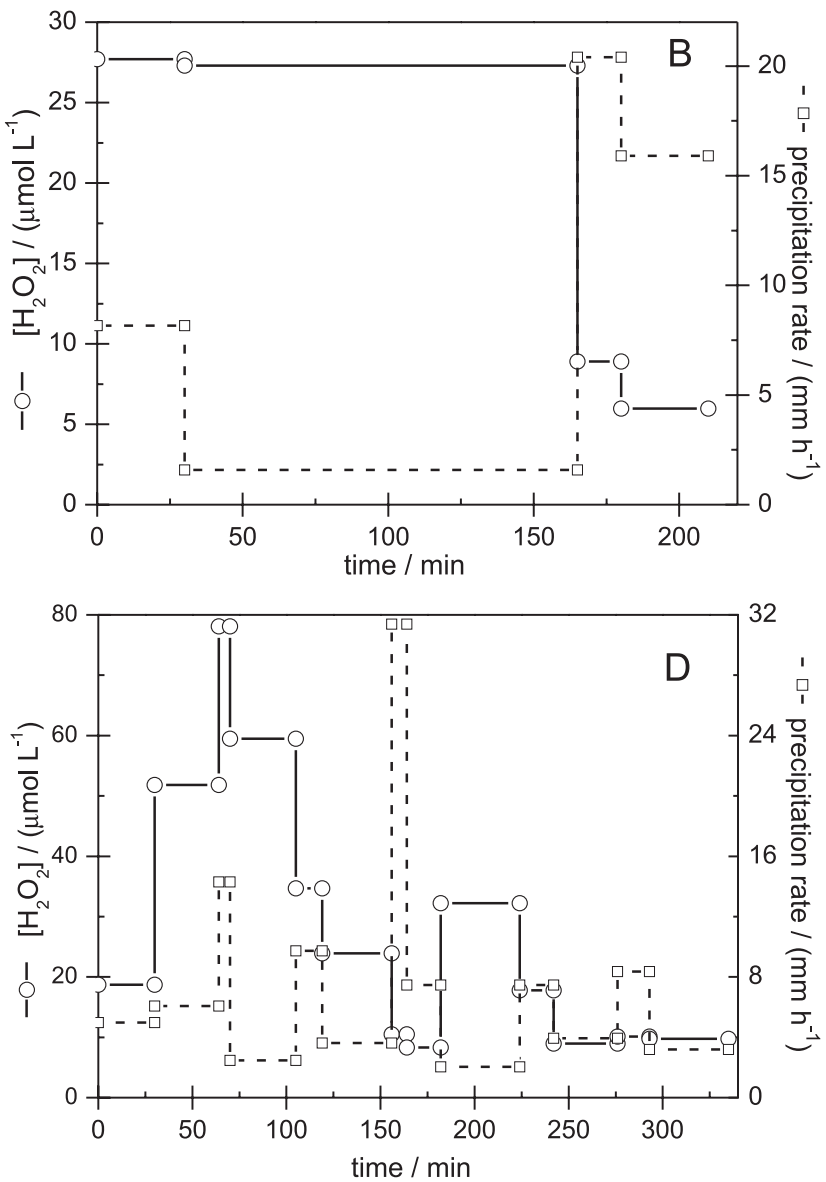

Figure 4. Profiles of $\mathrm{H}_{2} \mathrm{O}_{2}$ concentrations and precipitation rates during sequential rainwater events: A) October 9, 2003; B) November 28, 2002; C) November 16, 2004; D) September 20, 2002. 
The significant increase in $\mathrm{H}_{2} \mathrm{O}_{2}$ content may be attributed to the occurrence of intense activity of lightning in the area observed in the first $30 \mathrm{~min}$ of rain. ${ }^{33}$ In subsequent rain fractions (Figure 4d), the $\mathrm{H}_{2} \mathrm{O}_{2}$ concentration declined continuously until $18 \mathrm{~mm}$ of rainfall. The raise of $\mathrm{H}_{2} \mathrm{O}_{2}$ concentration at the end of rain may have been a result of the reduction precipitation rate, which usually favours the removal processes of atmospheric hydrogen peroxide.

These sequential analyses in the rainstorm show that the previous meteorological conditions, lightning and rainfall rate can influence the $\mathrm{H}_{2} \mathrm{O}_{2}$ contents in rainwater in Sao Paulo.

\section{Conclusions}

The concentrations of $\mathrm{H}_{2} \mathrm{O}_{2}, \mathrm{SO}_{4}{ }^{2-}, \mathrm{HCOO}^{-}$and $\mathrm{H}^{+}$ were measured in rainwater collected in the center of Sao Paulo City between July 2001 and January 2006. The $\mathrm{H}_{2} \mathrm{O}_{2}$ concentrations in rainwater ranged from 0.5 to $78.1 \mu \mathrm{mol} \mathrm{L}^{-1}$ with an average value of $14.5 \mu \mathrm{mol} \mathrm{L} \mathrm{L}^{-1}$. The concentrations of $\mathrm{H}_{2} \mathrm{O}_{2}$ exhibited a seasonal variation in rainwater with higher values obtained in the spring and lower in the winter. The $\mathrm{pH}$ values ranged from 4.13 to 7.18 , presenting a mean value of 5.10 and VWM of 5.14, suggesting that the rainfall was slightly acidic. The hydrogen peroxide concentrations showed a positive correlation with sulfate and hydrogen ion concentrations, which suggests that the decomposition of hydrogen peroxide by reaction with $\mathrm{SO}_{2}$ is not predominant in the rainwater in Sao Paulo City.

A positive and significant correlation was observed between $\mathrm{H}_{2} \mathrm{O}_{2}$ and $\mathrm{HCOO}^{-}$concentrations, showing that the production of $\mathrm{H}_{2} \mathrm{O}_{2}$ in aqueous phase by consumption of formaldehyde by reaction with $\mathrm{OH}^{*}$ radical can be a factor controlling the $\mathrm{H}_{2} \mathrm{O}_{2}$ levels in the rainwater in this area. The main source of aldehydes in rainwater is the gas-phase aldehydes which are emitted by combustion of the ethanol and gasohol (a mix of gasoline and $22 \%$ of ethanol), the most common fuels used in almost six million light vehicles in MASP. Additionally, the dissolution of gaseous $\mathrm{H}_{2} \mathrm{O}_{2}$ and/or its production by lightning activities during thunderstorms may also contribute to the hydrogen peroxide concentrations in the rainwater of Sao Paulo City.

The levels of $\mathrm{H}_{2} \mathrm{O}_{2}$ were not controlled by dilution. However, there was a significant inverse correlation between the concentrations of $\mathrm{H}_{2} \mathrm{O}_{2}$ and the precipitation rate, indicating that lower rainfall rates conduct to higher $\mathrm{H}_{2} \mathrm{O}_{2}$ contents in several rainstorms. The estimated annual rate of $\mathrm{H}_{2} \mathrm{O}_{2}$ wet deposition was $12 \mathrm{mmol} \mathrm{m}^{-2} \mathrm{y}^{-1}$, and $70 \%$ of this amount is deposited in the spring and in the summer, approximately. The temporal measurements of the $\mathrm{H}_{2} \mathrm{O}_{2}$ concentrations monitored in thirteen rainstorms show a diurnal variation in rainwater $\mathrm{H}_{2} \mathrm{O}_{2}$ concentrations being the higher contents of $\mathrm{H}_{2} \mathrm{O}_{2}$ measured in rains occurying in the early afternoons after sunny mornings. Lightning activities and the rainfall rate were important factors which affected the $\mathrm{H}_{2} \mathrm{O}_{2}$ contents during the rainstorms.

\section{Acknowledgments}

The authors acknowledge Fundação de Amparo à Pesquisa do Estado de Sao Paulo (FAPESP) and Fundo Mackenzie de Pesquisa (MACKPESQUISA) for the financial support of this work.

\section{References}

1. Sakugawa, H.; Kaplan, I. R.; Tsai, W.; Cohen, Y.; Environ. Sci. Technol. 1990, 24, 1452.

2. Gunz, D. W.; Hoffmann, M. R.; Atmos. Environ. 1990, 24A, 1601.

3. Lee, M. H.; Heikes, B. G.; O'Sullivan, D. W.; Atmos. Environ. 2000, 34, 3475.

4. Reeves, C. E.; Penkett, S. A.; Chem. Rev. 2003, 103, 5199.

5. Macdonald, A. M.; Anlauf, K. G.; Banic, C. M.; Leaitch, W. R.; Wiebe, H. A.; J. Geophys. Res. 1995, 100(D4), 7253.

6. Peña, R. M.; García, S.; Herrero, C.; Lucas, T.; Atmos. Environ. 2001, 35, 209.

7. Chung, M.Y.; Muthana S.; Paluyo, R.N.; Hasson, A.S.; Atmos. Environ. 2005, 39, 2981.

8. Faust, B. C.; Anastasio, C.; Allen, J. M.; Arakaki, T.; Science 1993, 260, 73 .

9. Balasubramanian, R.; Husain L.; J. Geophys. Res. 1997, 102, 21209.

10. Ortiz, V.; Rubio, M. A.; Lissi, E. A.; Atmos. Environ. 2000, 34, 1139.

11. Sowka, I.; Zwozdziak, J.; Zwozdziak, A.; Szczurek, A.; Water, Air, Soil Pollut. 2004, 155, 321.

12. Padilla, H.; Torres, M. C.; Belmont, R.; Garcia, R.; Mendoza, E.; Baez, A.; Chemistry and Ecology 2007, 23, 325.

13. Jacob, P.; Tavares, T. M.; Rocha, V. C.; Klockow, D.; Atmos. Environ. 1990, 24, 377.

14. Matos, R. C.; Pedrotti, J. J.; Angnes, L.; Anal. Chim. Acta 2001, 441, 73-79.

15. Matos, R. C.; Coelho, E. O.; Souza, C. F.; Guedes, F. A.; Matos, M. A. C.; Talanta 2006, 69, 1208.

16. Santos, M. A.; Pedrotti, J. J.; Fornaro, A. In Highway and Urban Environment, Proceedings of the $8^{\text {th }}$ Highway and Urban Environment Symposium; Morrison, G. M.; Rauch, S., eds., Springer: Dordrech, 2007, ch. 2.

17. Fornaro, A.; Gutz, I. G. R.; Atmos. Environ. 2006, 40, 5893. 
18. CETESB. Relatório de Qualidade do Ar no Estado de São Paulo, 2006, Secretaria do Meio Ambiente, Série Relatórios, ISSN 0103-4103, São Paulo, Brasil, 2007. (http://www.cetesb. sp.gov.br/Ar/relatorios/RelatorioAr2006.zip).

19. Leal, T. F. M.; Fontenele, A. P. G.; Pedrotti, J. J.; Fornaro, A.; Quim. Nova 2004, 27, 855.

20. Santos, M. A.; Illanes, C. A. F.; Fornaro, A.; Pedrotti, J. J.; Water, Air, Soil Pollut.: Focus 2007, 7, 85.

21. Kawamura, K.; Steinberg, S.; Ng, L.; Kaplan, I. R.; Atmos. Environ. 2001, 35, 3917.

22. Gonçalves, C.; Matos, R. C.; Pedrotti, J. J.; Abstracts do $11^{\circ}$ Encontro Nacional de Química Analítica, Campinas, Brasil, 2001.

23. Deng, Y.; Zuo, Y.; Atmos. Environ. 1999, 33, 1469.

24. Seinfeld, J. H.; Pandis, S. N.; Atmospheric Chemistry and Physics - From Air Pollution to Climate Change, $2^{\text {nd }}$ ed., John Wiley \& Sons, Inc.: Hoboken, 2006.

25. Kieber, R. J.; Rhines, M. F.; Willey, J. D.; Avery, G. B. Jr.; Atmos. Environ. 1999, 33, 3659.

26. Finlayson-Pitts, B. J.; Pitts, J. N.; Chemistry of the Upper and Lower Atmosphere - Theory, Experiments, and Applications, Academic Press: San Diego, 2000.
27. Montero, L.; Vasconcelos, P. C.; Souza, S. R.; Pires, M. A. F.; Sanchez-Ccoyllo, O.; Andrade, M. F.; Carvalho, L. R. F.; Environ. Sci. Technol. 2001, 35, 3071.

28. Nguyen, H. T.; Takenaka, N.; Bandow, H.; Maeda, Y.; Oliva, S. T.; Botelho, M. M. F.; Tavares, T. M.; Atmos. Environ. 2001, 35, 3075 .

29. Yamada, E.; Tomozawa, K.; Nakanishi,Y.; Fuse, Y.; Bull. Chem. Soc. Jpn. 2002, 75, 1385.

30. Willey, J. D.; Kieber, R. J.; Lancaster, R. D.; J. Atmos. Chem. 1996, 25, 149.

31. Sakugawa, H.; Kaplan, I. R.; Shepard, L. S.; Atmos. Environ. 1993, 27, 203.

32. Kok, G. L.; Atmos. Environ. 1980, 14, 653.

33. Zuo, Y.; Deng, Y.; Geochimica et Cosmochimica Acta 1999, 63, 3451 .

Received: May 20, 2009

Web Release Date: November 26, 2009

FAPESP helped in meeting the publication costs of this article. 